\title{
Effect of medium-pH and MES on adventitious root formation from stem disks of apple
}

\author{
Geert-Jan de Klerk · Jana Hanecakova • \\ Jan Jásik
}

Received: 24 May 2008/Accepted: 1 August 2008/Published online: 21 August 2008

(C) The Author(s) 2008. This article is published with open access at Springerlink.com

\begin{abstract}
We have examined the effect of medium$\mathrm{pH}$ on rooting using 1-mm slices cut from stems of apple microshoots. Before autoclaving, the $\mathrm{pH}$ of the rooting medium was set at various $\mathrm{pH}$ values between 4.5 and 8.0. During autoclaving, the $\mathrm{pH}$ drifted in particular in the alkaline region. Additional changes occurred during culture and the range set at 4.5-8.0 had shifted to 5.2-6.0 after autoclaving and 3 weeks of culture. When $10 \mathrm{mM}$ 2-( $N$-morpholino)ethanesulfonic acid (MES) had been added as buffering agent, the $\mathrm{pH}$ was stable when set at 5.0-6.5. Highest rooting was achieved at $\mathrm{pH} \sim 5.3$ with and without MES ( $\mathrm{pH}$ measured after autoclaving). This maximum did not correlate with highest auxin uptake. MES inhibited adventitious root formation during the initial phase of root formation when the meristemoids are being formed (ca. $30 \%$ reduction at $10 \mathrm{mM}$ ) but was promotive during outgrowth of the meristemoids to roots $(30 \%$ increase at $10 \mathrm{mM})$. Inhibition and promotion by MES were not related to its buffering action as they were observed at all pHs.
\end{abstract}

\footnotetext{
G.-J. de Klerk $(\square)$ · J. Hanecakova · J. Jásik

Wageningen Tissue Culture Center, Biodiversity and Breeding, Wageningen University and Research, PO Box 16, 6700 AA Wageningen, The Netherlands e-mail: geertjan.deklerk@wur.nl

J. Hanecakova · J. Jásik

Department of Plant Physiology, Comenius University, Mlynska dolina B2, 84215 Bratislava, Slovakia
}

\section{Keywords MES - Rooting $\cdot$ Malus}

\begin{abstract}
Abbreviations
IAA Indoleacetic acid

IBA Indolebutyric acid

MES 2-(N-morpholino)ethanesulfonic acid

MS Murashige Skoog (1962)
\end{abstract}

\section{Introduction}

Plant tissue culture media are poorly buffered (Leifert et al. 1992; Vacin and Went 1949). From the various common medium components, only phosphate has buffering capacities, but the concentration of phosphate is low (1.25 mM in MS). Moreover, phosphate is rapidly taken up from the medium (Leifert et al. 1995). The $\mathrm{pH}$ of tissue culture media decreases among others by uptake of $\mathrm{NH}_{3}{ }^{+}$, and increases by uptake of $\mathrm{NO}_{3}{ }^{-}$(e.g. Schmitz and Lorz 1990). A change of medium-pH may have various effects that may influence performance and development of the explants (George et al. 2008). (1) In semi-solid media, the availability of many compounds is pH-dependent (Arnon et al. 1942; Scholten and Pierik 1998; Van Winkle et al. 2003). (2) Uptake of medium components by the explants may be influenced directly by the $\mathrm{pH}$. This holds in particular for uptake of auxins (see Discussion). (3) The $\mathrm{pH}$ influences enzymatic and other chemical reactions in 
the medium. In this context, it is important to note that in media, especially near explants, enzymes and other compounds occur released from explants either because of wounding at subculturing or during culture by excretion/secretion. (4) Finally, low $\mathrm{pH}$ prevents agar from solidifying.

It has been reported that medium-pH influences developmental processes in tissue culture, among others regenerative processes: xylogenesis in Citrus and Zinnia elegans (Khan et al. 1986; Roberts and Haigler 1994); androgenesis in winter triticale and wheat (Karsai et al. 1994), adventitious bud regeneration in tobacco (Pasqua et al. 2002) and adventitious root formation in apple (Harbage et al. 1998). For xylogenesis in Z. elegans, it has been reported that the effect of $\mathrm{pH}$ correlates with changes in uptake of auxin (Shinohara et al. 2006).

In this paper, we report the effect of $\mathrm{pH}$ and the buffer MES on rooting of 1-mm thick slices cut from stems of apple microcuttings. These explants are very suitable to study the effect of $\mathrm{pH}$ on rooting because they are tiny, thereby minimizing the role of the explant itself. As auxin is a key factor in rooting, the effects of $\mathrm{pH}$ on IAA uptake and decarboxylative oxidation have been examined.

\section{Materials and methods}

Apple shoot cultures

Shoot production of Malus 'Jork 9' was maintained as described previously (De Klerk et al. 1995). Shoots of $1 \mathrm{~cm}$ were cultured in tubes with $15 \mathrm{ml}$ propagation medium. After 5 weeks at $25^{\circ} \mathrm{C}$ and a 16-h photoperiod $\left(35 \mu \mathrm{mol} \mathrm{m} \mathrm{m}^{-2} \mathrm{~s}^{-1}\right.$ provided by cool white fluorescent lamps), clusters consisting of 5-10 shoots had been formed by axillary branching. Shoots were excised and either used for further shoot proliferation or for preparing 1-mm slices.

\section{Preparation and culture of 1-mm slices}

The leaves were removed from the stems and 1-mm slices were cut with a device consisting of 11 razor blades separated by $1-\mathrm{mm}$ metal plates. Slices cut from the middle $1 \mathrm{~cm}$ of stems, show no effect of the position of the slice in the stem (apical, middle, basal) (de Klerk and Caillat 1994). The slices were cultured with the apical side down on a nylon mesh on top of $30 \mathrm{ml}$ of rooting medium in a 9-cm Petri dish (De Klerk et al. 1995). The Petri dish was incubated upside down in the dark in a culture room at $25^{\circ} \mathrm{C}$. The concentrations and type of auxin are indicated for each experiment. The medium was solidified with $0.7 \%$ agar (BBL granulated) with the exception of the experiment with labelled IAA in which $0.2 \%$ gelrite was used to allow determinations at low pH (Fig. 5). After 5 days of culture in the dark, the slices were transferred to hormone-free medium and to the light. For this transfer, the nylon mesh with the slices attached was transferred. Excess liquid was removed by placing the mesh on filter paper ( $5 \mathrm{~s})$. In each Petri dish, 30 slices originating from six shoots were cultured. The five slices taken from each shoot were nonadjacent because it has been shown previously there exists a (weak) correlation between the capabilities to root of adjacent slices; there is no correlation between the rooting of nonadjacent slices (De Klerk and Caillat 1994). Roots were counted after 21 days under a dissecting microscope. MES was added as indicated for each experiment. The $\mathrm{pH}$ was set before autoclaving and varied as indicated for each experiment. The $\mathrm{pH}$ was set and measured with a conventional $\mathrm{pH}$ meter.

Uptake and oxidation of $1-{ }^{14} \mathrm{C}$-IAA

The experiments were performed in 2-cm high 9-cm Petri dishes. The dishes contained $20 \mathrm{ml}$ rooting medium (De Klerk et al. 1995) with $10 \mu \mathrm{M}$ IAA. One kBq [1- $\left.{ }^{14} \mathrm{C}\right]$ IAA (Sigma, $1.4810^{6} \mathrm{kBq} \mathrm{mmol}^{-1}$ ) was added as a tracer. Both uptake of the label by explants and ${ }^{14} \mathrm{CO}_{2}$ (formed by oxidation of $\left.\left[1-{ }^{14} \mathrm{C}\right] \mathrm{IAA}\right)$ in the headspace of the Petri dish were measured. For uptake, samples of three slices were taken at random and digested in $200 \mu$ l Soluene-350 (Packard) overnight at $40^{\circ} \mathrm{C}$. Then $4.5 \mathrm{ml}$ HionicFluor (Packard) was added, and ${ }^{14} \mathrm{CO}_{2}$ was trapped in $300 \mu 12 \mathrm{M} \mathrm{KOH}$ in a small vial with a piece of filter paper. To determine the amount of radioactivity, $4.5 \mathrm{ml}$ Ultima Gold (Packard) was added to the $300 \mu \mathrm{KOH}$ solution and the filter paper.

\section{Statistics}

For the determination of root numbers, three Petri dishes with 30 slices each were used for each 
treatment and for the experiments with $\left[1-{ }^{14} \mathrm{C}\right] \mathrm{IAA}$, two Petri dishes with 30 slices each. Uptake of the label was determined by taking two samples of three slices from each dish (four samples in total). The data on ${ }^{14} \mathrm{CO}_{2}$ are means of two Petri dishes. To establish the significance of the $\mathrm{pH}$-effect in Fig. 5, we calculated whether the slope of the regression line was significantly different from zero.

\section{Results}

Shift of $\mathrm{pH}$ during autoclaving and culture and the effect of MES

Without addition of MES, the agar did not solidify when the $\mathrm{pH}$ had been set at 4.0 or lower, so the lowest $\mathrm{pH}$ looked at was 4.5. A large shift of $\mathrm{pH}$ occurred after autoclaving, especially when the $\mathrm{pH}$ had been set higher than 6.0 or higher (Fig. 1). In all cases, the $\mathrm{pH}$ dropped: the initial range of 4.5-8.0 changed to 4.4-5.5. During culture, the $\mathrm{pH}$ continued to change in medium without MES and always increased relative to the $\mathrm{pH}$ just after autoclaving. The range 4.4-5.5 (measured after autoclaving) changed to 5.2-5.8 after 21 days of culture (Fig. 1). When the $\mathrm{pH}$ had initially been set at 5.5 (close to the $\mathrm{pH}$ at which tissue culture media are usually set), the changes were small.

With addition of $10 \mathrm{mM}$ MES, the agar did not solidify at $\mathrm{pH} 4.5$. With $10 \mathrm{mM}$ MES, after autoclaving a large $\mathrm{pH}$ shift occurred only at $\mathrm{pH}>6.5$. This is beyond the buffering capacity of MES (Good et al. 1966). There was no or only a minor additional change during culture (Fig. 1). MES is the buffer of choice for tissue culture media because it buffers in the appropriate range $(\mathrm{pH}$ 5.5-6.7) and supposedly has little or no effects unrelated to buffering (Banthorpe and Brown 1990; Good et al. 1966; Parfitt et al. 1988). In preliminary experiments, though, we observed an inhibitory effect of MES on rooting. A dose-response curve confirmed the inhibitory effect (Fig. 2). Therefore, a low MES concentration of $10 \mathrm{mM}$ was taken for the experiments.

In the experiment shown in Fig. 2, MES had been added during the initial 5 days only. During this period, three distinct steps may be distinguished on basis of their hormonal requirements: (1) dedifferentiation (0-24 h), (2) induction (24-96 h), and (3)

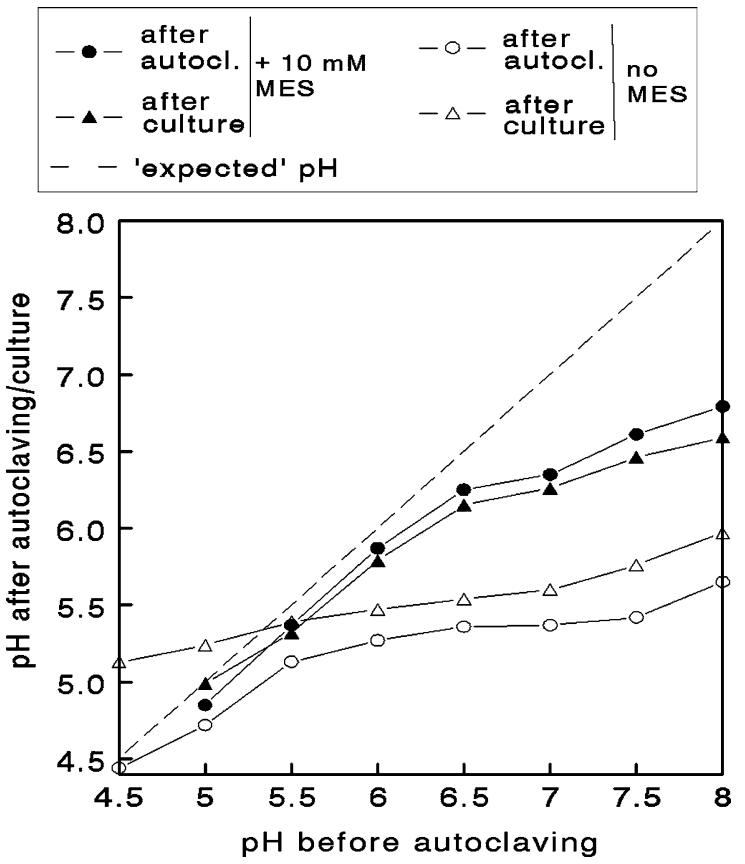

Fig. 1 Effects of autoclaving and 3 weeks of culture on $\mathrm{pH}$ of nutrient medium with or without $10 \mathrm{mM}$ MES

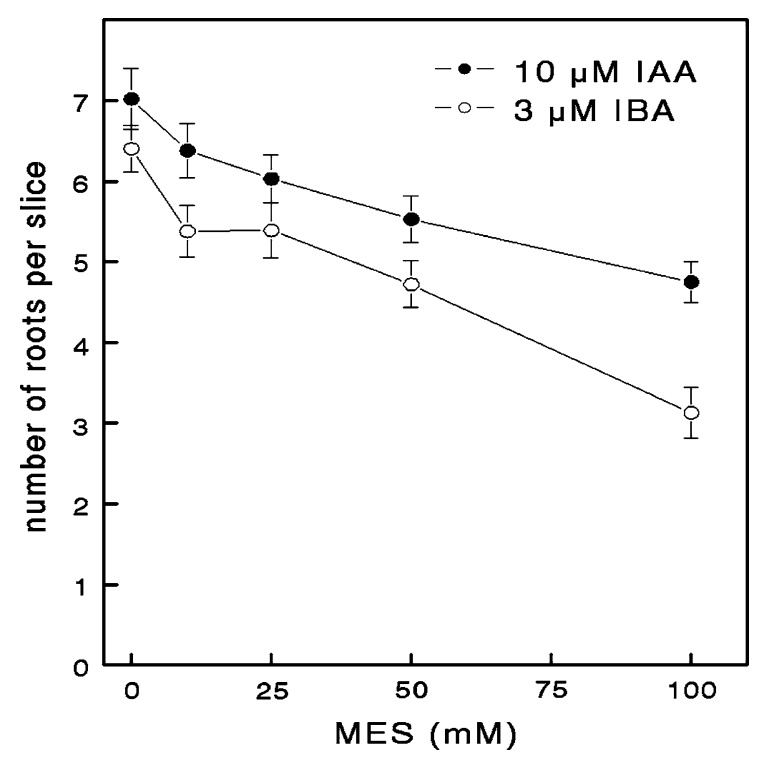

Fig. 2 Effect of MES (pH 5.5) on adventitious root formation from 1-mm thick stem slices excised from microcuttings of Malus 'Jork 9'. MES and auxins were applied for the initial 5 days only. After that the slices were transferred to hormonefree medium without MES

differentiation (from $96 \mathrm{~h}$ onwards) (see for explanation De Klerk et al. 1995). We examined whether the inhibition by MES is similar in these phases by 
giving 24 h-pulses with MES. Figure 3 shows that inhibition strongly depended on the timing of the pulse with highest inhibition during pulses at the 3rd and 4th day, so during step 2 , the induction phase.

The effect of $\mathrm{pH}$ on rooting

To examine the effect of $\mathrm{pH}$, slices were cultured the initial 5 days at various $\mathrm{pHs}$ with or without $10 \mathrm{mM}$ MES and after that transferred to standard medium. During this initial period, the root meristems are being formed (Jásik and De Klerk 1997). In Fig. 4a, the number of regenerated roots is plotted as a function of the $\mathrm{pH}$ measured at the time of transfer of slices to the Petri dishes (the $\mathrm{pH}$ just after autoclaving). The $\mathrm{pH}$ had a significant effect on the number of adventitious roots. Highest rooting was at $\mathrm{pH} \sim 5.3$ both with and without addition of MES. MES inhibited rooting by $30-50 \%$. The shape of the $\mathrm{pH}$ response curves with and without MES were similar, indicating that the inhibition by MES was not related to its buffering action.

We also examined the effect of the $\mathrm{pH}$ on outgrowth of the meristems to roots. For this experiment, the slices were cultured 5 days on rooting medium with an

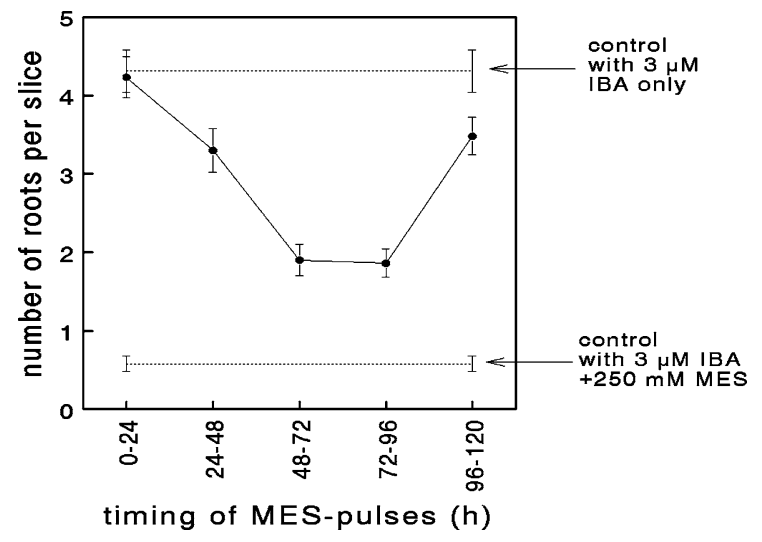

Fig. 3 Effect of 24-h pulses with $250 \mathrm{mM}$ MES ( $\mathrm{pH} 5.5$ ) on rooting of $1-\mathrm{mm}$ stem slices excised from microcuttings of Malus 'Jork 9'. Slices were cultured for 5 days on medium containing $3 \mu \mathrm{M}$ IBA and the pulses with MES were given at the indicated periods. During the MES-pulses, $3 \mu \mathrm{M}$ IBA was also present in the medium. After the 5-days period, the slices were transferred to hormone-free medium and to the light. A control with $3 \mu \mathrm{M}$ IBA only and a second control with $3 \mu \mathrm{M}$ IBA $+250 \mathrm{mM}$ MES were also carried out. In these controls, no $24 \mathrm{~h}$ transfers were made. It has been found previously that $24 \mathrm{~h}$ transfer to fresh medium does not influence rooting. The numbers of roots were counted after 21 days optimal concentration of IBA $(3 \mu \mathrm{M})$ at standard $\mathrm{pH}$ without MES and then transferred to auxin-free media at a range of $\mathrm{pHs}$ with or without MES. Again the numbers of roots are plotted as a function of the $\mathrm{pH}$ measured at the time of transfer. Figure $4 \mathrm{~b}$ shows that there is no effect of $\mathrm{pH}$. Interestingly, during this stage MES has a promotive effect $(P<0.001)$. This stimulating effect occurred at all $\mathrm{pHs}$ tested, indicating again that its effect was unrelated to its buffering action.
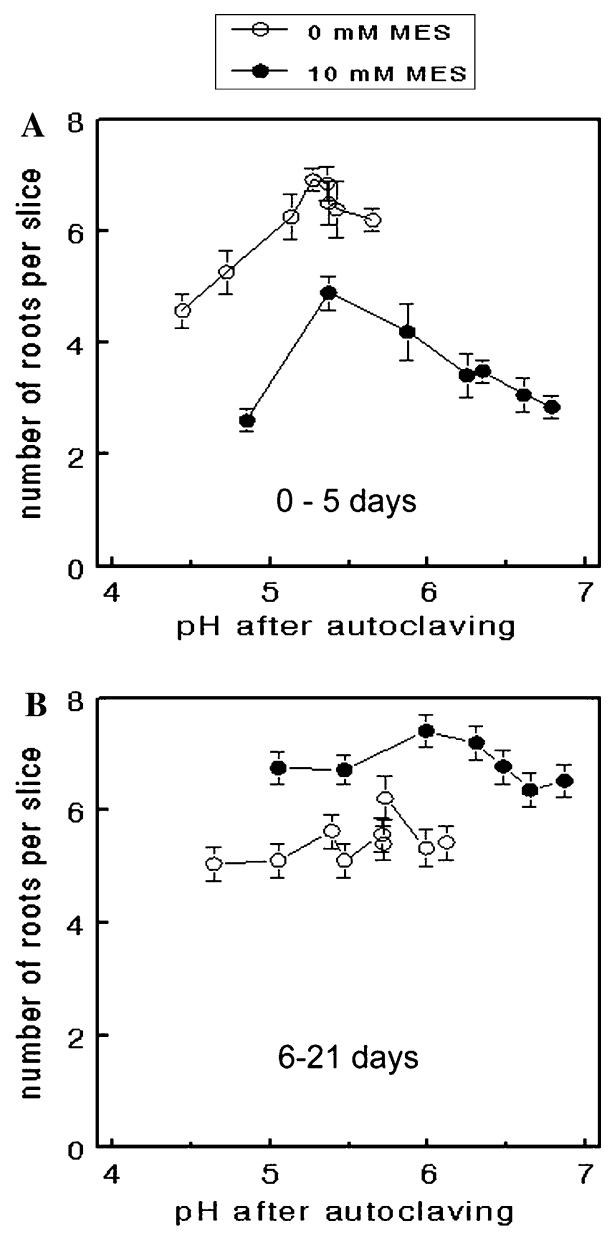

Fig. 4 Effect of $\mathrm{pH}$ on adventitious root formation from 1-mm thick stem slices excised from microcuttings of Malus 'Jork 9'. The $\mathrm{pH}$ at the $\mathrm{x}$-axis is the $\mathrm{pH}$ measured after autoclaving. The $\mathrm{pH}$ was either the $\mathrm{pH}$ of the standard rooting medium $(0 \mathrm{mM}$ MES) or rooting medium with $10 \mathrm{mM}$ MES. In (a) the effect of $\mathrm{pH}$ during the initial 5 days was determined with $3 \mu \mathrm{M}$ IAA. After that, the slices were transferred to standard medium without auxin and without MES. In (b) the effect of the $\mathrm{pH}$ in the following 6-21 days was determined: the slices were cultured with $3 \mu \mathrm{M}$ IBA and after 5 days transferred to hormone-free medium with increasing $\mathrm{pHs}$ 
Effect of $\mathrm{pH}$ on IAA uptake and oxidation

Increased rooting may be related to increased uptake of auxin. Therefore we examined uptake of auxin at a range of pHs. As IAA is massively decarboxylated (Guan and De Klerk 2000), we also examined the effect of $\mathrm{pH}$ on oxidation. When slices were cultured at a range of $\mathrm{pHs}$, both uptake and oxidation of IAA increased with decreasing $\mathrm{pH}$ (for all: $P<0.002$ ). In this experiment, the $\mathrm{pH}$ was kept stable by $10 \mathrm{mM}$ MES. The experiment was carried out with gelrite to get solid medium at low $\mathrm{pH}$. In the range that has been studied (4.5-7) both uptake and oxidation were highest at the lowest $\mathrm{pH}$. A decrease of the $\mathrm{pH}$ from 7 to 4.5 doubled both oxidation and uptake (Fig. 5).

With respect to the $\mathrm{pH}$-effect on oxidation, the "site of action" is not known: Oxidation may occur both within and outside the tissue and at the interphase. Since apple stem explants excrete peroxidases (P. Huisman and G. J. de Klerk unpublished results) and peroxidases oxidize auxins (Gazaryan et al. 1999), oxidation of IAA in the medium is likely. We examined this with slices that had first been preincubated for $24 \mathrm{~h}$. In this way, enzymes released from damaged cells, were avoided. The preincubated slices were incubated for $24 \mathrm{~h}$ on

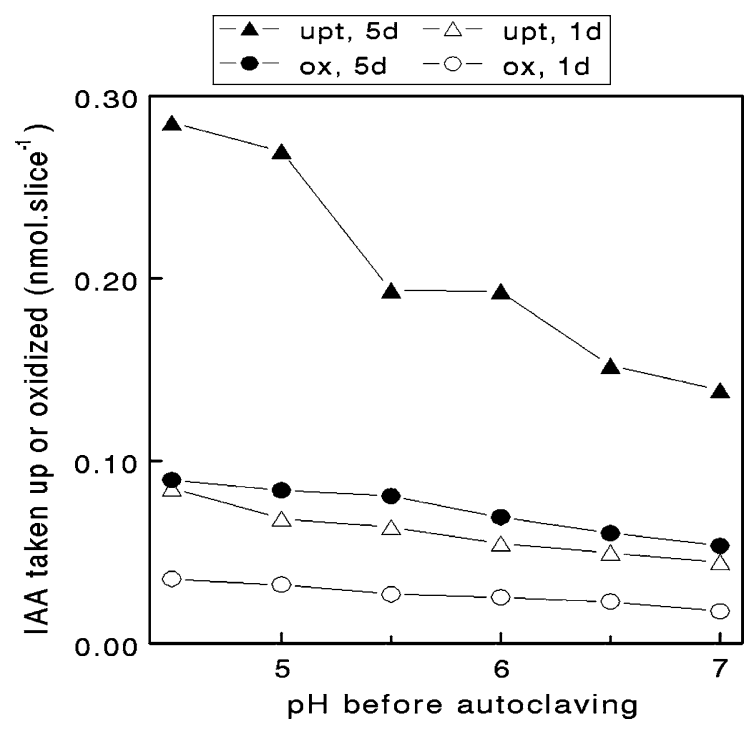

Fig. 5 Effect of $\mathrm{pH}$ on uptake and oxidation of IAA after 1 day of culture on medium with $10 \mu \mathrm{M}$ IAA and a tracer amount of ${ }^{14} \mathrm{C}$-IAA. The medium was solidified with $0.2 \%$ gelrite to enable experimentation at low $\mathrm{pH}$. Uptake and oxidation were measured after 1 and 5 days medium with labelled IAA and then removed. Oxidation of IAA was determined both during the $24 \mathrm{~h}$ culture period and during the following $24 \mathrm{~h}$ in the absence of slices. Since photooxidation was avoided by culture in the dark, measured oxidation has been brought about by compounds released into the medium from the slices. Significant oxidation occurred during the $24 \mathrm{~h}$ period without slices (Table 1). Similar results were obtained when the slices had been preincubated for $48 \mathrm{~h}$.

\section{Discussion}

Stability of $\mathrm{pH}$ and the morphogenetic effect of MES

To evaluate the effect of $\mathrm{pH}$, the actual $\mathrm{pH}$ in the medium is important. Various studies have shown that the $\mathrm{pH}$ of tissue culture media is poorlycontrolled and shifts both during autoclaving and during culture (e.g. Skirvin et al. 1986; Vacin and Went 1949). We obtained similar results (Fig. 1). Thus we measured the $\mathrm{pH}$ after autoclaving and plotted this $\mathrm{pH}$ in the graphs in Fig. 4. It should be noted that both during autoclaving and during culture, the change at $\mathrm{pH} 5.5$ (this is close to the $\mathrm{pH}$ commonly used in tissue culture) was only slight (Fig. 1). When MES buffer had been added to maintain the $\mathrm{pH}$, the shift in the range 5.0-6.5 was reduced to ca. $0.2 \mathrm{pH}$ units.

MES is considered to be an inert buffer but toxic at high concentration (>10 mM; Parfitt et al. 1988). An interesting finding of this paper is the inhibition by MES during the initial 5 days of the rooting treatment (Fig. 4a) and the promotive effect during the outgrowth of meristemoids to roots (Fig. 4b). As both promotion and inhibition occurred at all pHs, they were not related to the buffering action of MES. The timing of inhibition by MES was established more precisely by giving $24 \mathrm{~h}$ pulses with MES. We found stage-specific inhibition during the induction phase, i.e. the period during which the root meristemoids are being formed by the rhizogenic action of auxin (De Klerk et al. 1995). The promotion of outgrowth of primordia and the stage-specific inhibition show that the effect of MES is not caused by toxicity. The morphogenetic effect of MES corresponds with the effect of an anti-auxin. There are several reports in 
Table 1 Oxidation of IAA

\begin{tabular}{lll}
\hline & $\begin{array}{l}\text { Oxidation during } \\
24 \mathrm{~h} \text { in the } \\
\text { presence of slices } \\
\left(\text { nmol IAA slice }{ }^{-1}\right)\end{array}$ & $\begin{array}{l}\text { Oxidation during } \\
\text { the next 24 h in } \\
\text { the absence of slices } \\
\left(\mathrm{nmol} \mathrm{IAA} \mathrm{slice}^{-1} \text { ) }\right.\end{array}$ \\
\hline $\begin{array}{l}\text { 24 h preincubation } \\
48 \text { h preincubation }\end{array}$ & 0.083 & 0.028 \\
\end{tabular}

Slices were preincubated for $24 \mathrm{~h}$ or $48 \mathrm{~h}$ on medium without carboxyl labelled IAA, then transferred for $24 \mathrm{~h}$ to medium to which a tracer amount of ${ }^{14} \mathrm{C}$-IAA had been added and after that transferred back to the previous medium. Oxidation of ${ }^{14} \mathrm{C}$-IAA was determined in the Petri dishes with labelled medium both during the presence of slices and in the $24 \mathrm{~h}$ period after that (when no slices were in the dish). The dishes always contained $10 \mu \mathrm{M}$ IAA and were kept in the dark to avoid photooxidation

which biological effects of low concentrations of MES (10 mM or less) have been reported. In peach embryo culture, MES decreased embryo survival (Sinclair and Byrne 2003). In Medicago species, MES promoted nodulation (Ewing and Robson 1991). In Hyoscyamus niger, the formation of morphological abnormal somatic embryos was observed at $10 \mathrm{mM}$ MES (Tu et al. 1996). Baker et al. (2007) report that MES at concentrations of $5 \mathrm{mM}$ and higher can interfere with the oxidation of certain phenolics. It is interesting to note that an other biological buffer, piperazine, has a major stimulating effect on adventitious root formation (Liu et al. 1995).

The effect of $\mathrm{pH}$ on rooting

The $\mathrm{pH}$ influenced rooting during the first 5 days when the root meristems are being formed whereas after that during the period in which the meristemoids develop into roots, the $\mathrm{pH}$ had virtually no effect. For assessment of the mechanisms underlying the $\mathrm{pH}$ effect, it is important to discriminate between the various locations where the $\mathrm{pH}$ might have an effect: (1) the explant, (2) the medium and (3) the interface between explant and medium.

Within the cells in the explants, the various compartments have different $\mathrm{pH}$ values and the $\mathrm{pH}$ is maintained (Felle 2001). In the symplasm, the $\mathrm{pH}$ of the cytoplasm is $\sim 7$ and of the vacuole $\sim 5$. The apoplasm has a $\mathrm{pH}$ of $\sim 5$. The maintenance of the $\mathrm{pH}$ is illustrated in an experiment with detached leaves of Vicia faba (Felle and Hanstein 2002). When the leaves were placed in a $10 \mathrm{mM}$ MES-TRIS buffer and the $\mathrm{pH}$ was changed, the changes in $\mathrm{pH}$ in the apoplast were small: With an initial buffer $\mathrm{pH}=4.1$ and transfer to buffer $\mathrm{pH}=6.8$, the apoplastic $\mathrm{pH}$ of substomatal cavities increased from 4.68 to 5.14 and in the reverse transfer decreased from 5.16 to 4.70 . This indicates that the $\mathrm{pH}$ of the apoplasm is not strongly influenced by the medium but stays close to the 'natural' $\mathrm{pH}$ of ca. 5.0. The symplasm has a much larger capacity to buffer (Felle 2001) so the pH of cytoplasm and vacuole will be even less influenced by the medium-pH. So, within the explant the $\mathrm{pH}$ of both apoplast and symplast will be hardly affected by the medium-pH, in particular when no buffering agent has been added. This probably also applies to the site in the apple stem disks from where the roots are regenerated which is a few cell-layers from the cut surface (Jásik and De Klerk 1997). It should also be noted that we observed the effect of the $\mathrm{pH}$ both with and without MES (Fig. 3a). In conclusion, the site of action of the medium-pH is most probably the medium and/or the interface between explant and medium.

The most important candidate to explain the $\mathrm{pH}-$ effect is auxin uptake. Depending on the $\mathrm{pH}$ and their $\mathrm{pKa}$, auxins are either present as undissociated molecule or as anion. In the apoplast, the $\mathrm{pH}$ is low (ca. 5) so a large percentage of auxin is present as undissociated molecules that may pass through the membrane by diffusion. The anion may be taken up by a carrier (Delbarre et al. 1996; Morris 2000). In the cytoplasm (ca. pH 7), most auxin is present as anion and cannot diffuse out. So, auxin uptake expectedly increases with a decrease of the $\mathrm{pH}$. Figure 5 shows that indeed uptake increases with a decrease of the $\mathrm{pH}$.

The $\mathrm{pH}$ may also influence (enzymic) reactions. The explant excretes peroxidases in the medium and some peroxidases oxidize IAA. Peroxidases have an 
acidic pH optimum (Zmrhal and Machackova 1978). Indeed, we found a $\mathrm{pH}$-effect corresponding to an acidic $\mathrm{pH}$ optimum (Fig. 5). Thus, at low $\mathrm{pH}$ less label would occur in the slices because of increased oxidation. As we found the opposite, more label at low $\mathrm{pH}$, the effect op low $\mathrm{pH}$ on uptake is more significant than appears at first sight from Fig. 5.

The optimal $\mathrm{pH}$ during the initial 5 days was $\sim 5.3$ (Fig. 4a). At pH higher than 5.3, both auxin uptake and rooting decreased (Fig. 5). So in this case, decreased rooting may have been brought about by decreased auxin uptake. At $\mathrm{pH}$ lower than 5.3, auxin uptake increased (Fig. 5) and rooting decreased. Obviously, the decrease in rooting cannot be attributed to altered auxin uptake. It should be noted here that we actually did not determine auxin in the uptake experiments, but label after adding labelled IAA (Fig. 5). After uptake, auxin is massively conjugated and as a result inactivated. Harbage et al. (1998) did find an effect of $\mathrm{pH}$ on auxin uptake but not on auxin conjugation. Therefore, the amount of label is probably an accurate indication of the amount of IAA in the tissue. The decrease of rooting at $\mathrm{pH}<5.3$ may be explained altered uptake of specific medium compounds, among others inorganic nutrients (cf. Pasqua et al. 2002).

Open Access This article is distributed under the terms of the Creative Commons Attribution Noncommercial License which permits any noncommercial use, distribution, and reproduction in any medium, provided the original author(s) and source are credited.

\section{References}

Arnon DI, Fratzke WE, Johnson CM (1942) Hydrogen ion concentration in relation to absorption of inorganic nutrients by higher plants. Plant Physiol 17:515-524

Baker CJ, Mock NM, Roberts DP, Deahl KL, Hapeman CJ, Schmidt WF et al (2007) Interference by MES [2-(4morpholino)ethanesulfonic acid] and related buffers with phenolic oxidation by peroxidase. Free Radic Biol Med 43:1322-1327. doi:10.1016/j.freeradbiomed.2007.07.020

Banthorpe DV, Brown GD (1990) Growth and secondary metabolism in cell-cultures of Tanacetum, Mentha and Anethum species in buffered media. Plant Sci 67:107-111. doi: 10.1016/0168-9452(90)90056-T

De Klerk GJ, Caillat E (1994) Rooting responses of stem-disks excised from the same 'M9 Jork' microcutting. Adv Hortic Sci 8:15-18

De Klerk GJ, Keppel M, Ter Brugge J, Meekes H (1995) Timing of the phases in adventitious root formation in apple microcuttings. J Exp Bot 46:965-972. doi:10.1093/ $\mathrm{jxb} / 46.8 .965$
Delbarre A, Muller P, Imhoff V, Guern J (1996) Comparison of mechanisms controlling uptake and accumulation of 2, 4-dichlorophenoxy acetic acid, naphthalene-1-acetic acid, and indole-3-acetic acid in suspension-cultured tobacco cells. Planta 198:532-541. doi:10.1007/BF00262639

Ewing MA, Robson AD (1991) The use of MES buffer in early nodulation studies with annual Medicago species. Plant Soil 131:199-206. doi:10.1007/BF00009449

Felle HH (2001) pH: signal and messenger in plant cells. Plant Biol 3:577-591. doi:10.1055/s-2001-19372

Felle HH, Hanstein S (2002) The apoplastic pH of the substomatal cavity of Vicia faba leaves and its regulation responding to different stress factors. J Exp Bot 53:73-82. doi:10.1093/jexbot/53.366.73

Gazaryan IG, Chubar TA, Mareeva EA, Lagrimini LM, Van Huystee RB, Thorneley RNF (1999) Aerobic oxidation of indole-3-acetic acid catalysed by anionic and cationic peanut peroxidase. Phytochemistry 51:175-186. doi: 10.1016/S0031-9422(98)00758-4

George EF, Hall MA, De Klerk GJ (eds) (2008) Plant propagation by tissue culture. Vol 1: The background, 3rd edn. Springer, Dordrecht

Good NE, Winget GD, Winter W, Connolly TN, Izawa S, Singh RMM (1966) Hydrogen ion buffers for biological research. Biochemistry 5:467-477. doi:10.1021/bi00866 a011

Guan H, De Klerk GJ (2000) Stem segments of apple microcuttings take up auxin predominantly via the cut surface and not via the epidermal surface. Sci Hortic (Amsterdam) 86:23-32. doi:10.1016/S0304-4238(00)00132-1

Harbage JF, Stimart DP, Auer C (1998) pH affects $1 \mathrm{H}$-indole3-butyric acid uptake but not metabolism during the initiation phase of adventitious root induction in apple microcuttings. J Am Soc Hortic Sci 123:6-10

Jásik J, De Klerk GJ (1997) Anatomical and ultrastructural examination of adventitious root formation in stem slices of apple. Biol Plant 39:79-90. doi:10.1023/A:1000313207486

Karsai I, Bedo Z, Hayes PM (1994) Effect of induction medium $\mathrm{pH}$ and maltose concentration on in vitro androgenesis of hexaploid winter triticale and wheat. Plant Cell Tissue Organ Cult 39:49-53. doi:10.1007/BF00037591

Khan A, Chauhan YS, Roberts LW (1986) In vitro studies on xylogenesis in Citrus fruit vesicles. 2. Effect of $\mathrm{pH}$ of the nutrient medium on the induction of cytodifferentiation. Plant Sci 46:213-216. doi:10.1016/0168-9452(86)90194-9

Leifert C, Pryce S, Lumsden PJ, Waites WM (1992) Effect of medium acidity on growth and rooting of different plant species growing in vitro. Plant Cell Tissue Organ Cult 30:171-179. doi:10.1007/BF00040019

Leifert C, Murphy KP, Lumsden PJ (1995) Mineral and carbohydrate nutrition of plant cell and tissue cultures. Crit Rev Plant Sci 14:83-109. doi:10.1080/713608070

Liu JH, Yeung EC, Mukherjee I, Reid DM (1995) Stimulation of adventitious rooting in cuttings of four herbaceous species by piperazine. Ann Bot (Lond) 75:119-125. doi: 10.1006/anbo.1995.1002

Morris DA (2000) Transmembrane auxin carrier systemsdynamic regulators of polar auxin transport. Plant Growth Regul 32:161-172. doi:10.1023/A:1010701527848

Parfitt DE, Almehdi AA, Bloksberg LN (1988) Use of organic buffers in plant tissue-culture systems. Sci Hortic 
(Amsterdam) 36:157-163. doi:10.1016/0304-4238(88) 90049-0

Pasqua G, Manes F, Monacelli B, Natale L, Anselmi S (2002) Effects of the culture medium $\mathrm{pH}$ and ion uptake in in vitro vegetative organogenesis in thin cell layers of tobacco. Plant Sci 162:947-955. doi:10.1016/S0168-9452 (02)00048-1

Roberts AW, Haigler CH (1994) Cell expansion and tracheary element differentiation are regulated by extracellular $\mathrm{pH}$ in mesophyll cultures of Zinnia elegans L. Plant Physiol 105:699-706

Schmitz U, Lorz H (1990) Nutrient-uptake in suspension-cultures of gramineae. 2. Suspension-cultures of rice (Oryza Sativa L.). Plant Sci 66:95-111. doi:10.1016/0168-9452 (90)90174-M

Scholten HJ, Pierik RLM (1998) Agar as a gelling agent: chemical and physical analysis. Plant Cell Rep 17:230235. doi:10.1007/s002990050384

Shinohara N, Sugiyama M, Fukuda H (2006) Higher extracellular $\mathrm{pH}$ suppresses tracheary element differentiation by affecting auxin uptake. Planta 224:394-404. doi: 10.1007/s00425-006-0224-1
Sinclair JW, Byrne DH (2003) Improvement of peach embryo culture through manipulation of carbohydrate source and pH. Hort Sci 38:582-585

Skirvin RM, Chu MC, Mann ML, Young H, Sullivan J, Fermanian T (1986) Stability of tissue culture medium $\mathrm{pH}$ as a function of autoclaving, time, and cultured plant material. Plant Cell Rep 5:292-294. doi:10.1007/BF00269825

Tu S, Tétu T, Sangwan RS, Sangwan-Norreel BS (1996) Effect of 2-( $N$-morpholino)ethanesulfonic acid and myo-inositol on somatic embryogenesis and plant regeneration from zygotic embryos of Hyoscyamus niger L. Plant Sci 114:193-203. doi:10.1016/0168-9452(95)04315-2

Vacin EF, Went FW (1949) Some pH changes in nutrient solutions. Bot Gaz 110:605-613. doi:10.1086/335561

Van Winkle SC, Johnson S, Pullman GS (2003) The impact of Gelrite and activated carbon on the elemental composition of two conifer embryogenic tissue initiation media. Plant Cell Rep 21:1175-1182. doi:10.1007/s00299-003-0637-2

Zmrhal Z, Machackova I (1978) Isolation and characterization of wheat peroxidase isoenzyme B1. Phytochemistry 17:1517-1520. doi:10.1016/S0031-9422(00)94632-6 